\title{
Pengaruh discretionary accrual terhadap earnings management: Studi pada perusahaan otomotif yang terdaftar di bursa efek indonesia periode 2012 - 2016 (The effect of discretionary accrual on earnings management: Study on automotive companies listed in Indonesia stock exchange in 2012-2016)
}

Ersi Sisdianto ${ }^{1}$, Rahmat Fajar Ramdani ${ }^{2}$, Ainul Fitri ${ }^{3}$

Universitas Islam Negeri Raden Intan Lampung ${ }^{1,2,3}$

ersisisdianto@ radenintan.ac.id ${ }^{1}$, rahmatfajar@ radenintan.ac.id ${ }^{2}$, ainulfitri@ radenintan.ac.id ${ }^{3}$

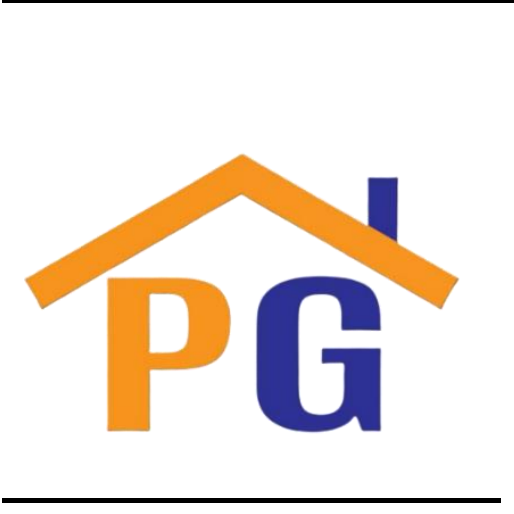

Riwayat Artikel

Diterima pada 7 November 2019

Revisi 1 pada 20 November 2019

Revisi 2 pada 28 November 2019

Revisi 3 pada 4 Desember 2019

Revisi 4 pada 4 Desember 2019

Revisi 5 pada 5 Desember 2019

Disetujui pada 5 Desember 2019

\begin{abstract}
Purpose: This study aims to provide an overview of the effect of discretionary accruals on earnings management.

Research methodology: The research uses quantitative methods that take secondary data from annual financial statements.

Results: The results show that discretionary accruals have a positive and significant effect on earnings management in the automotive and component sector manufacturing companies listed on the Indonesia Stock Exchange in 2012-2016.

Limitation: This study only discusses how much influence of discretionary accruals on earnings management. Also, the number of samples and populations are less than 100 samples. Thus, it is possible for further research to conduct similar research with more samples.

Contribution: This research provides new literature related to the effect of discretionary accruals on earnings management.

Keywords: Discretionary accrual, Non discretionary accrual earnings management, Profit reporting

How to cite: Sisdianto, E., Ramdani, R. F., dan Fitri, A. (2019). Pengaruh discretionary accrual terhadap earnings management (Studi pada perusahaan otomotif yang terdaftar di Bursa Efek Indonesia periode 2012 - 2016). Jurnal Akuntansi, Keuangan, dan Manajemen, 1(1), 27-38.
\end{abstract}

\section{Pendahuluan}

Scott (2012) menjelaskan tentang manajemen laba menjadi dua. Pertama manajemen laba sebagai perilaku oportunistik manajemen untuk memaksimalkan utilitasnya dalam menghadapi kontrak kompensasi, kontrak utang dan political costs (opportunistic earnings management). Kedua, memandang manajemen laba dari sudut pandang efficient contracting (Efficient Earning Management), di mana manajemen laba memberi manajemen suatu fleksibilitas untuk melindungi diri mereka dan perusahaan dalam mengantisipasi kejadian-kejadian yang tidak terduga untuk kepentingan pihak-pihak yang terlibat dalam kontrak. Dengan demikian, manajemen dapat mempengaruhi nilai pasar saham perusahaannya melalui manajemen laba, misalnya dengan membuat perataan laba (income smoothing) dan pertumbuhan laba sepanjang waktu. 
Menurut Scott (2015) terdapat empat pola manajemen laba, yaitu :

- Taking a bath

Pola ini dilakukan ketika reorganisasi termasuk pengangkatan CEO baru, yaitu dengan melaporkan kerugian dalam jumlah besar. Tindakan ini diharapkan dapat meningkatkan laba di masa mendatang.

- Income Minimization

Pola yang dilakukan pada saat perusahaan mengalami tingkat profitabilitas yang tinggi sehingga jika laba pada periode mendatang diperkirakan turun drastis, maka hal ini dapat diatasi dengan mengambil laba periode sebelumnya.

- Income Maximization

Pola manajemen laba ini dilakukan pada saat laba menurun. Tindakan income minimization bertujuan untuk melaporkan net income yang tinggi untuk tujuan bonus yang lebih besar. Pola ini dilakukan oleh perusahaan yang melakukan pelanggaran perjanjian hutang.

- Income Smoothing

Dilakukan perusahaan dengan cara meratakan laba yang dilaporkan sehingga dapat mengurangi flukuasi laba yang terlalu besar karena pada umumnya investor lebih menyukai laba yang relative stabil.

Dalam menjalankan operasinya, suatu perusahaan secara periodik menyiapkan laporan keuangan untuk pihak-pihak yang berkepentingan seperti pemegang saham, investor dan pemerintah. Laporan keuangan berfungsi sebagai salah satu informasi yang digunakan untuk menilai kinerja perusahaan. Akan tetapi perusahaan yang terdaftar di Bursa Efek Indonesia sangat banyak dimana masing-masing perusahaan telah mempublikasikan laporan keuangannya agar para calon investor dapat melihat kinerja setiap perusahaan. Salah satunya dengan melihat fluktuasi laba perusahaan tersebut. Fluktuasi laba adalah suatu bentuk manipulasi laba agar jumlah laba suatu periode tidak terlalu berbeda dengan jumlah laba periode sebelumnya.

Oleh karena itu usaha untuk mengurangi fluktuasi laba, dalam hal ini manajemen mempunyai kecenderungan untuk melakukan tindakan yang dapat membuat laporan keuangan menjadi baik, informasi yang terkandung di dalam laporan keuangan tersebut menjadi salah satu faktor yang mempengaruhi keputusan yang diambil oleh perusahaan. Tindakan manajemen untuk mengatur laba perusahaan sesuai keinginannya disebut manajemen laba (earnings management).

Manajemen laba merupakan suatu fenomena menarik yang telah menambah wacana dalam perkembangan teori akuntansi. Kasus yang terjadi pada Enron Corp., WorldCom Inc., Global Crossing Ltd, Kimia Farma, Xerox Corporation dan Indofarma merupakan beberapa bukti kemampuan dan kemauan manajemen dalam memanipulasi laporan keuangan, terutama yang berkaitan dengan laba perusahaan.

Salah satu kasus manajemen laba yang baru-baru ini terjadi adalah skandal akuntansi yang dilakukan Toshiba. Seperti yang dimuat dalam money.cnn.com oleh Yan (2015), kasus ini bermula ketika Toshiba sendiri mulai menyelidiki praktik akuntansi di divisi energi. Menurut sebuah komite independen, perusahaan menggelembungkan laba usaha Toshiba sebesar $¥ 151.8$ milyar (\$1,2 milyar) selama tujuh tahun. Kepala eksekutif Toshiba dan presiden Hisao Tanaka mengundurkan diri atas skandal akuntansi yang mengguncang perusahaan. Delapan anggota dewan, termasuk wakil ketua Norio Sasaki, juga telah mengundurkan diri dari jabatan mereka sebagai bagian dari perombakan besar manajemen perusahaan. Akibat skandal akuntansi yang mengguncang perusahaan, saham Toshiba telah turun sekitar $20 \%$ sejak awal april ketika isu-isu akuntansi ini terungkap. Nilai pasar perusahaan hilang sekitar $¥ 1.673$ triliun (\$13.4 milyar) dan para analis memperkirakan saham Toshiba masih akan terus menurun. Toshiba yang merupakan salah satu merek elektronik paling dikenal di dunia serta memiliki reputasi yang bagus itu kini menurun drastis akibat skandal akuntansi yang telah dilakukan perusahaan

Di Indonesia skandal terjadi tahun 2002 dengan kasus Kimia Farma, mencatat overstated laba pada laba bersih untuk tahun yang berakhir 31 Desember 2001 sebesar Rp. 32,7 miliar dengan cara memanipulasi kesalahan dalam penilaian persediaan barang jadi dan kesalahan pencatatan penjualan. Selanjutnya tahun 2004 kasus Indofarma dengan mencatat harga pokok penjualan terlalu rendah (understated) sebesar Rp. 28,8 miliar dan laba bersih disajikan terlalu tinggi (overstated) dengan nilai 
yang sama, hal ini dilakukan dengan manipulasi nilai barang dalam proses dinilai lebih tinggi dari nilai yang seharusnya.

Fenomena manajemen laba telah banyak dijadikan objek dalam berbagai penelitian, dengan mengungkapkan keberadaan manajemen laba yang dikaitkan dengan faktor-faktor tertentu. Beberapa penelitian sebelumnya seperti Watt dan Zimmerman (1986;1990) Philips, Pincus dan Rego (2003), Yin dan Ceng (2004), Scoot; Sumomba et al (2012) lebih banyak memfokuskan pada motivasi dalam hal perpajakan.

\section{Landasan teori}

\subsection{Teori sinyal (Signalling theory)}

Teori Sinyal (signalling theory) menjelaskan mengapa perusahaan mempunyai dorongan untuk memberikan informasi laporan keuangan pada pihak eksternal. Dorongan perusahaan untuk memberikan informasi dikarenakan terdapat asimetri informasi antara perusahaan dan pihak luar, sebab perusahaan mengetahui lebih banyak mengenai perusahaan dan prospek yang akan datang daripada pihak luar (investor dan kreditor). Kurangnya informasi pihak luar mengenai perusahaan menyebabkan mereka melindungi diri dengan memberikan harga yang rendah untuk perusahaan.Perusahaan dapat meningkatkan nilai perusahaan, dengan mengurangi informasi asimetri.

\subsection{Teori akuntansi positif (Positive accounting theory)}

Teori akuntansi positif adalah sebuah teori yang mencoba untuk membuat prediksi yang bagus dari kejadian di dunia nyata. Teori akuntansi positif berkaitan dengan memprediksi tindakan seperti misalnya pemilihan kebijakan akuntansi oleh manajer (agen) di suatu perusahaan dan bagaimana respon manajer terhadap standar akuntansi baru yang diusulkannya itu ( Scott, 2012). Berdasarkan teori akuntansi positif hal tersebut akan memunculkan adanya aliran positif dari beberapa ahli.

\subsection{Discretionary accrual}

Dalam akuntansi dikenal dengan istilah basis akrual dan basis kas. Pendekatan yang sering digunakan adalah pendekatan akrual, akuntansi akrual dianggap lebih baik daripada akuntansi berbasis kas karena akrual adalah suatu metode perhitungan penghasilan dan biaya dalam arti penghasilan diakui pada waktu diperoleh dan biaya diakui pada waktu terhutang (Muljono, 2009:28).

Sistem akuntansi akrual memberikan peluang kepada manajemen untuk memanipulasi laba atau pendapatan akuntansi (De Angelo, 1986; dalam Dahlan, 2009). Akuntansi akrual tersebut dapat dibagi menjadi dua yaitu discretionary accruals dan non-discretionary accruals. Konsep discretionary accruals memberi pengertian bahwa pihak manajemen dapat memanipulasi pendapatan akrual dan biasanya digunakan untuk mencapai pendapatan yang diinginkan. De Angelo (1986) dalam Meutia (2004) menambahkan bahwa manajer memiliki kemampuan mengontrol bagian akrual dalam jangka pendek. De Angelo juga menjelaskan bahwa komponen non-discretionary accruals ditentukan oleh faktor-faktor lain yang tidak dapat dikontrol oleh pihak manajer. Di dalam penelitian ini, perhitungan manajemen laba menggunakan Model Jones yaitu discretionary accrual yang sesuai dengan kinerja (performance-matched discretionary accruals). Berdasarkan pada Kothari et al., (2005), performance-matched discretionary accruals pengukurannya lebih spesifik dan powerfull daripada pengukuran discretionary accruals yang lain. Kothari menjelaskan juga bahwa penyeimbangan kinerja (performance matching) didesain untuk mengontrol dampak kinerja dalam mengukur discretionary accruals dan performance-matched discretionary accruals dapat dijadikan sebagai alternatif yang dapat dipakai dalam meneliti manajemen laba.

\subsection{Earnings management}

Scott (2012) menjelaskan tentang manajemen laba menjadi dua. Pertama manajemen laba sebagai perilaku oportunistik manajemen untuk memaksimalkan utilitasnya dalam menghadapi kontrak kompensasi, kontrak utang dan political costs (opportunistic earnings management). Kedua, memandang manajemen laba dari sudut pandang efficient contracting (Efficient Earning Management), di mana manajemen laba memberi manajemen suatu fleksibilitas untuk melindungi diri mereka dan perusahaan dalam mengantisipasi kejadian-kejadian yang tidak terduga untuk kepentingan pihak-pihak yang terlibat dalam kontrak. Dengan demikian, manajemen dapat 
mempengaruhi nilai pasar saham perusahaannya melalui manajemen laba, misalnya dengan membuat perataan laba (income smoothing) dan pertumbuhan laba sepanjang waktu.

Manajemen laba dapat didefinisikan sebagai pelaporan keuangan yang tidak netral yang didalamnya manajer secara intensif melakukan kegiatan untuk menghasilkan beberapa keuntungan pribadi. Manajer dapat melakukan kegiatan dengan memodifikasi tentang bagaimana manajer menginterpretasikan berbagai standar akuntansi keuangan dan data akuntansi (Healy dan Wahlen, 1999).

\section{Metode penelitian}

Dalam penelitian ini, penulis menggunakan penelitian kuantitatif dimana proses penggalian informasi diwujudkan dalam bentuk angka-angka sebagai alat untuk menemukan keterangan mengenai apa yang diketahui. Penelitian kuantitatif lebih menekankan fenomena-fenomena objektif, dan maksimalisasi objektivitas, desain penelitian ini dilakukan dengan menggunakan angka-angka, pengolahan statistik, struktur dan percobaan terkontrol (Moleong, 2011:2). Penelitian kuantitatif mencakup setiap jenis penelitian yang didasarkan atas perhitungan persentase, rata-rata, dan perhitungan lainnya. Dengan kata lain penelitian ini menggunakan perhitungan angka atau kuantitas (Moleong, 2011:1).

Menurut Menurut Sugiyono (2017 : 7) Metode kuantitatif adalah : "Metode kuantitatif dapat diartikan sebagai metode pasitivistik karena berlandasan pada filsafat positivisme. Penelitian kuantitatif yang digunakan adalah kuantitatif kausal karena bertujuan untuk menguji hipotesis tentang pengaruh. Berdasarkan jenis investigasinya, penelitian ini termasuk dalam penelitian kausal karena penelitian ini ingin menemukan penyebab atau hubungan sebab akibat dari satu atau lebih masalah seperti yang telah dinyatakan dalam rumusan masalah (Sekaran \&Bougie, 2010:165).

Berdasarkan waktunya penelitian ini adalah cross sectional yaitu penelitian yang dilakukan pada periode waktu tertentu dan untuk mengumpulkan data yang berkaitan dalam rangka menemukan jawaban atas pertanyaan penelitian (Sekaran \& Bougie, 2010:178).

\subsection{Populasi dan sampel penelitian}

Populasi yang digunakan dalam penelitian ini adalah seluruh perusahaan automotif yang terdaftar di Bursa Efek Indonesia (BEI) tahun 2012 - 2016. Menurut Sugiyono (2016:80) mendefinisikan populasi sebagai berikut: "Populasi adalah wilayah generalisasi yang terdiri atas objek atau subyek yang mempunyai kualitas dan karakteristik tertentu yang ditetapkan oleh peneliti untuk dipelajari dan kemudian ditarik kesimpulannya." (Sugiyono, 2016).

Tujuan dari metode ini supaya sampel yang dipilih sesuai dengan tujuan masalah penelitian, sehingga memperkecil kesalahan dalam proses pemiihan data. Selain itu juga karena pertimbangan mengenai kelengkapan data dan ketersediaan data yang akan dikumpulkan. Sampel yang digunakan apabila memenuhi kriteria sebagai berikut:

- Perusahaan manufaktur sektor otomotif dan komponennya yang terdaftar di BEI periode 1 Januari 2012 sampai 31 Desember 2016.

- Perusahaan tidak melakukan merger dan akuisisi dari tahun 2012 sampai tahun 2016.

- Perusahaan tidak delisting atau keluar dari BEI selama periode 1 Januari 2012 sampai 31 Desember 2016.

- Laporan keuangan yang disajikan dalam mata uang asing akan disajikan dalam kurs rupiahnya.

- Laporan keuangan mempunyai data lengkap yang dibutuhkan.

Tabel 3.1

Daftar industri manufaktur sektor otomotif dan komponennya

\begin{tabular}{|c|c|l|}
\hline No & Kode Emiten & \multicolumn{1}{|c|}{ Nama Perusahaan } \\
\hline 1 & ASII & Astra Internasional \\
\hline 2 & AUTO & Astra Autopart \\
\hline 3 & BRAM & Indo Kordsa \\
\hline
\end{tabular}




\begin{tabular}{|c|c|l|}
\hline 4 & GDYR & Goodyear Indonesia \\
\hline 5 & GJTL & Gajah Tunggal \\
\hline 6 & IMAS & Indomobil Sukses Internasional \\
\hline 7 & INDS & Indospring \\
\hline 8 & LPIN & Multi Prima Sejahtera \\
\hline 9 & MASA & Multistrada Arah Sarana \\
\hline 10 & NIPS & Nipress \\
\hline 11 & PRAS & Prima Alloy Steel Universal \\
\hline 12 & SMSM & Selamat Sempurna \\
\hline
\end{tabular}

Sumber : Data dari Bursa Efek Indonesia (BEI)

\subsection{Teknik dan metode pengumpulan data}

Menurut Arikunto, (2006: 175) teknik pengumpulan data adalah cara yang digunakan oleh peneliti untuk memperoleh data yang dibutuhkan. Pada sebuah penelitian diperlukan sebuah alat ukur yang biasanya dinamakan instrumen penelitian. Jadi pengertian Menurut Sugiyono (2017 : 102) yang dimaksud dengan instrumen penelitian adalah sebagai berikut: "Instrumen penelitian adalah suatu alat yang digunakan mengukur fenomena alam maupun sosisal yang diamati."

Teknik pengumpulan data yang dipergunakan dalam penelitian ini dengan cara dokumentasi, menggunakan data sekunder yang diperoleh dari :

- Indonesian Capital Market Directory

- Website www.idx.co.id

Penelitian ini dianalisis dengan menggunakan empat jenis uji, yaitu: (1) statistik deskriptif, (2) uji asumsi klasik, (3) uji regresi dan (4) uji hipotesis. Penelitian ini menggunakan program SPSS 24 for Windows untuk pengolahan data.

\subsection{Hipotesis}

Menurut Sugiyono (2013:96), menyatakan bahwa hipotesis merupakan jawaban sementara terhadap rumusan masalah penelitian, di mana rumusan masalah dinyatakan dalam bentuk kalimat pernyataan. Dikatakan sementara karena jawaban yang diberikan baru didasarkan pada teori yang relevan, belum didasarkan pada fakta-fakta empiris yang diperoleh melalui pengumpulan data. Jadi, hipotesis dapat dinyatakan sebagai jawaban teoritis terhadap rumusan masalah penelitian, belum dijawab empirik.

\section{- Discretionary accruals dengan manajemen laba}

Hasil penelitian dengan menggunakan Modified Jones Model (Dechow et.al, 1995) menyatakan bahwa discretionary accrual tidak berpengaruh positif terhadap probabilitas perusahaan untuk melakukan manajemen laba.

Sedangkan Tomas J Sibarani et al (2015) menyatakan bahwa discretionary accrual berpengaruh signifikan terhadap manajemen laba serta memiliki hubungan yang positif antara discretionary accruals dengan manajemen laba yang artinya semakin besar discretionary accruals maka semakin besar peluang manajemen perusahaan melakukan tindakan manajeman laba.

Berdasarkan hasil penelitian-penelitian tersebut maka disusun hipotesis sebagai berikut :

H1 : Discretionary accrual berpengaruh terhadap manajemen laba.

\section{Hasil dan pembahasan}


Statistik deskritif digunakan untuk melihat distribusi data yang digunakan sebagai sampel. Statistik deskriptif menggambarkan distribusi data yang terdiri dari nilai minimum, nilai maksimum, nilai rata-rata, dan nilai standar deviasi atas data yang digunakan dalam penelitian ini.

Pengukuran manajemen laba dalam penelitian ini adalah tingkat pendapatan yang sering digunakan manajemm untuk melakukan manajemen laba. Analisis statistik deskriptif seperti pada tabel 4.1 menunjukkan bahwa nilai minimum dan maksimum dari masing-masing variabel. Nilai minimum merupakan nilai terendah untuk setiap variabel. Nilai maksimum merupakan nilai tertinggi untuk setiap variabel dalam penelitian ini. Nilai mean merupakan nilai rata-rata dari setiap variabel yang diteliti. Standar deviasi merupakan sebaran data yang digunakan dalam penelitian yang mencerminkan data tersebut homogen atau heterogen yang sifatnya fluktuatif.

\section{Tabel 4.1}

Statistik deskriptif

\begin{tabular}{|l|r|r|r|r|r|r|}
\hline & $\mathrm{N}$ & \multicolumn{1}{|c|}{ Range } & Minimum & Maximum & \multicolumn{1}{c|}{ Mean } & $\begin{array}{c}\text { Std. } \\
\text { Deviation }\end{array}$ \\
\hline & 60 & 5,7007 & $-3,5520$ & 2,1488 &,- 942120 & 1,1594730 \\
\hline $\begin{array}{l}\text { Discretionary } \\
\text { Accrual (X1) }\end{array}$ & 60 & 1,6500 &, 0700 & 1,7200 &, 919000 &, 4391737 \\
\hline $\begin{array}{l}\text { Manajemen Laba } \\
\text { (Y) }\end{array}$ & 60 & & & & & \\
\hline Valid N (listwise) & 60 & & & & & \\
\hline
\end{tabular}

Sumber: Ouput SPSS 24, 2017

Berdasarkan tabel 4.1 di atas dapat dilihat bahwa variabel manajemen laba memiliki nilai terendah 0.0700 dan nilai tertinggi 1.7200 dengan nilai rata-ratanya sebesar 0.919000 dan standar deviasinya 0.4391737 . Variabel discretionary accrual memiliki nilai terendah (-3.5520) dan nilai tertinggi 2.1488 dengan nilai rata-ratanya sebesar (-0.942120) dan standar deviasinya 1.1594730 .

Uji multikolinieritas bertujuan untuk menguji apakah model regresi ditemukan adanya korelasi antar variabel bebas. Uji multikolinieritas dengan menganalisis perhitungan nilai Tolerance dan Variance Inflation Factor (VIF). Nilai tolerance yang rendah sama dengan nilai VIF tinggi (karena VIF $=1 /$ tolerance). Nilai cut off yang umum dipakai untuk menunjukan adanya multikolinieritas adalah nilai tolerance $\leq 0,10$ atau sama dengan nilai VIF 10. Hasil lengkap pengujian multikoloniearitas dapat dilihat pada tabel 4.2 berikut:

\section{Tabel 4.2}

\section{Uji multikoloniearitas}

\begin{tabular}{|c|c|c|c|c|c|c|c|c|}
\hline \multicolumn{9}{|c|}{ Coefficients $^{\mathrm{a}}$} \\
\hline & & \multicolumn{2}{|c|}{$\begin{array}{l}\text { Unstandardized } \\
\text { Coefficients }\end{array}$} & \multirow{2}{*}{$\begin{array}{c}\text { Standardized } \\
\text { Coefficients } \\
\text { Beta }\end{array}$} & \multirow[t]{2}{*}{$\mathrm{T}$} & \multirow[t]{2}{*}{ Sig. } & \multicolumn{2}{|c|}{$\begin{array}{l}\text { Collinearity } \\
\text { Statistics }\end{array}$} \\
\hline \multicolumn{2}{|c|}{ Model } & B & Std. Error & & & & Tolerance & VIF \\
\hline \multirow[t]{2}{*}{1} & (Constant) & 808 & ,074 & & 10,883 & ,000 & & \\
\hline & $\begin{array}{l}\text { Discretionary } \\
\text { Accrual (X1) }\end{array}$ & ,124 & ,049 & 327 & 2,524 & ,014 & ,895 & 1,117 \\
\hline
\end{tabular}

\section{Sumber: Output SPSS 24, 2017}

Dari hasi uji dengan SPSS yang ditunjukkan dalam tabel 4.2 diketahui nilai tolerance variabel discretionary accrual adalah 0.895 lebih besar dari 0.10 . Nilai variance inflation factor (VIF) variabel discreationary accrual sebesar 1.117 lebih kecil dari 10. Jadi, dapat disimpulkan bahwa tidak terjadi mutikolinieritas dalam model regresi.

Uji ini bertujuan untuk mengetahui apakah ada korelasi antara anggota serangkaian data observasi yang diurutkan menurut waktu atau ruang. Dasar pengambilan keputusan uji autokorelasi adalah dengan melihat kriteria berikut: 
- Jika angka DW di bawah -2 berarti ada autokorelasi positif

- Jika angka DW di antara -2 dan +2 berarti tidak ada autokorelasi

- Jika angka DW di atas +2 berarti ada autokorelasi negatif

Hasil uji autokorelasi dapat dilihat pada tabel 4.3 berikut:

Tabel 4.3

Uji autokorelasi

\begin{tabular}{|l|c|c|r|r|r|}
\hline \multicolumn{7}{|c|}{ Model Summary $^{\mathbf{b}}$} \\
\hline Model & $\mathrm{R}$ & R Square & Adjusted R Square & $\begin{array}{l}\text { Std. Error of } \\
\text { the Estimate }\end{array}$ & Durbin-Watson \\
\hline 1 &, $401^{\mathrm{a}}$ &, 161 &, 116 &, 4129131 &, 962 \\
\hline \multicolumn{2}{|l}{ a. Predictors: (Constant), Discretionary Accrual (X1), } \\
\multicolumn{4}{l}{ b. Dependent Variable: Manajemen Laba (Y) } \\
\hline
\end{tabular}

Sumber: Outputs SPSS 24, 2017

Berdasarkan uji yang telah dilakukan maka didapatkan nilai uji Durbin-Watson sebesar 0.962. Kemudian nilai tersebut dibandingkan dengan kriteria pengujian yang telah ditetapkan.

Berdasarkan kriteria pengujian dan nilai uji Durbin-Watson diketahui sebesar 0.962 berada diantara -2 dan +2 sehingga dapat disimpulkan bahwa model regresi dalam penelitian ini tidak ada autokorelasi.

Uji heterokedastisitas bertujuan untuk menguji apakah dalam model regresi terjadi ketidaksamaan variance dari residual satu pengamatan ke pengamatan yang lain. Jika variance dari residual antar pengamatan tetap maka disebut homokedastisitas. Penelitian yang baik adalah yang homokedastisitas atau tidak terjadi heterokedastisitas. Uji heterokedasitisitas dalam penelitian ini menggunakan grafik scatterplot. Berikut tampilan grafik scatterplot dari model regresi dalam penelitian ini dapat dilihat pada gambar 4.1.

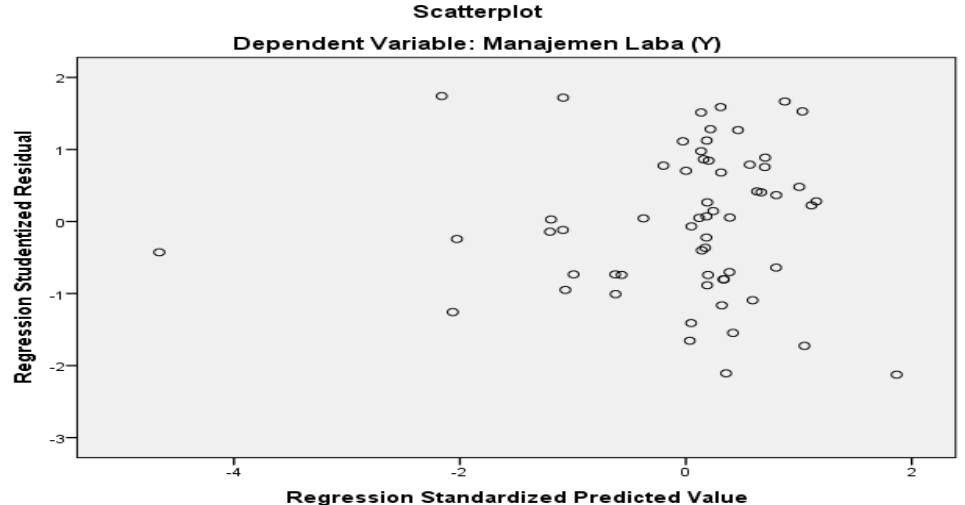

Sumber: Output SPSS 24

\section{Gambar 4.1}

\section{Uji heterokedasitisitas}

Berdasarkan gamabr 4.1 di atas dapat disimpulkan bahwa nilai titik-titik data menyebar di atas dan di bawah atau disekitar angka 0 (nol). Titik-titik tidak mengumpul hanya di atas atau dibawah saja, penyebaran titik-titik tidak membentuk pola bergelombang melebar kemudian menyempit dan melebar kembali dan penyebaran titik-titik tidak berpola. Artinya variabel tersebut tidak terjadi heterokedasitisitas atau data yang digunakan terbebas dari heterokedasitisitas.

Uji normalitas dimaksudkan untuk menguji apakah nilai residual yang telah terstandarisasi pada model regresi berdistribusi normal atau tidak. Uji normalitass dapat dilakukan dengan membandingkan nilai observasi (observed normal) dengan nilai yang diharapkan dari distribusi 
normal (expected normal). Jika data memperlihatkan distribusi normal, maka titiknya akan berada disekitar garis diagonal. Dalam penelitian ini uji normalitas data dapat dilihat pada grafik NORMAL Q-Q PLOT yang menunjukkan suatu distribusi data. Data dengan distribusi normal akan menyebar mendekati garis diagonal dan mengikuti alur ke kanan atas.

Hasil pengujian dapat dilihat pada gambar 4.2 dan gambar 4.3 berikut:

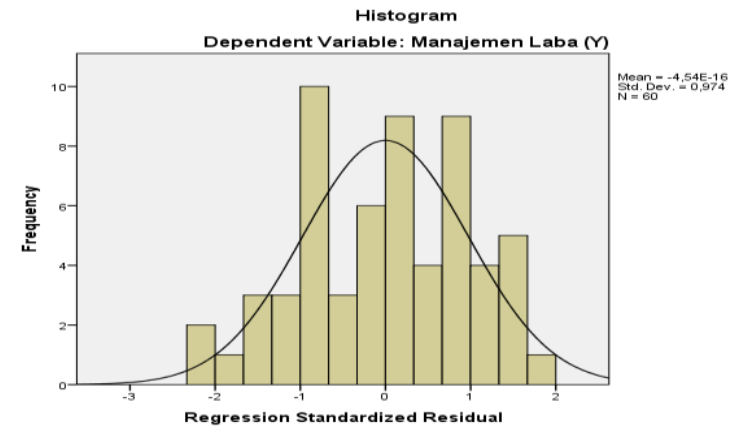

Gambar 4.2

Histogram Normalitas

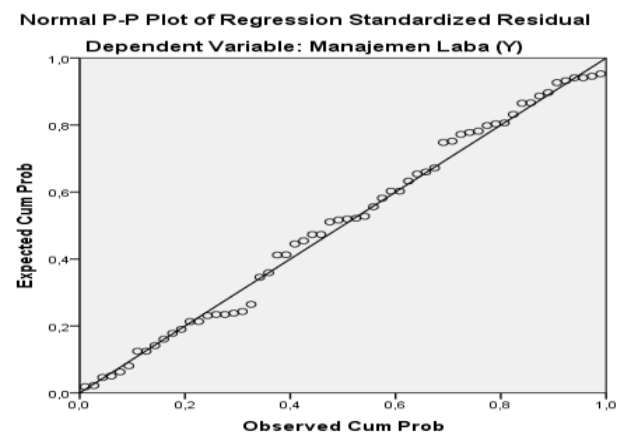

Sumber: Ouptut SPSS 24, 2017

Gambar 4.3

Grafik normalitas P-P Plot

Berdasarkan gambar 4.2 di atas dapat diketahui bahwa pola distribusi cenderung ke kanan yang artinya adalah data berdistribusi normal. Pada gambar 4.3 P-P plot diketahui titik-titik mengikuti dan mendekati garis diagonalnya sehingga dapat disimpulkan bahwa model regresi dalam penelitian ini memenubi asumsi normalitas.

Uji linearitas digunakan untuk melgb ihat kebenaran dari spesifikasi model yang digunakan. Uji ini bertujuan untuk menghasilkan F-hitung. Hasil dari F-hitung, dibandingkan dengan F tabel. Jika F hitung > F tabel, maka hipotesis nol yang menyatakan bahwa spesifikasi model dalam bentuk fungsi linear ditolak. Hasil lengkap dari uji linearitas masing-masing variabel adalah sebagai berikut:

Tabel 4.4

Uji linearitas variabel $\mathrm{X}_{1}$ terhadap $\mathrm{Y}$

\begin{tabular}{|c|c|c|c|c|c|c|c|}
\hline \multicolumn{8}{|c|}{ ANOVA Table } \\
\hline & & & $\begin{array}{l}\text { Sum of } \\
\text { Squares }\end{array}$ & Df & $\begin{array}{l}\text { Mean } \\
\text { Square }\end{array}$ & $\mathrm{F}$ & Sig. \\
\hline \multirow{5}{*}{$\begin{array}{l}\text { Manajemen Laba } \\
(Y) * \\
\text { Discretionary } \\
\text { Accrual (X1) }\end{array}$} & \multirow{3}{*}{\begin{tabular}{|l} 
Between \\
Groups
\end{tabular}} & (Combined) & 10,572 & 53 & ,199 & 1,481 & ,330 \\
\hline & & Linearity & 1,589 & 1 & 1,589 & 11,803 & ,014 \\
\hline & & $\begin{array}{l}\text { Deviation } \\
\text { from } \\
\text { Linearity }\end{array}$ & 8,982 & 52 & , 173 & 1,283 & 410 \\
\hline & \multicolumn{2}{|c|}{\begin{tabular}{|l} 
Within Groups \\
\end{tabular}} & ,808 & 6 & ,135 & & \\
\hline & \multicolumn{2}{|l|}{ Total } & 11,380 & 59 & & & \\
\hline
\end{tabular}




\section{Sumber: Output SPSS 24, 2017}

Berdasarkan tabel 4.4 diketahui bahwa nilai $\mathrm{F}$ Hitung sebesar 1.283. sedangkan nilai $\mathrm{t}$ tabel sebesar 3.16 yang berarti bahwa $\mathrm{f}$ hitung $<\mathrm{f}$ tabel $(1.025<3.16)$ dan nilai sig. deviation from linearity sebesar 0.410 atau lebih besar dari signifikansi 0.05, sehingga dapat disimpulkan bahwa ada hubungan linear antara variabel discretionary accrual $\left(\mathrm{X}_{1}\right)$ dengan manajemen laba $(\mathrm{Y})$. Dari nilai $\mathrm{F}$ hitung dan nilai signifikansi yang tersebut di atas dapat disimpulkan bahwa semua variabel discretionary accrual ada hubungan yang linear dengan manajemen laba.

Dalam penelitian ini yang menjadi variabel dependen adalah manajemen laba $(\mathrm{Y})$, sedangkan yang menjadi variabel independen adalah discretionary accrual $\left(\mathrm{X}_{1}\right)$. Sehingga persamaan regresi yang terbentuk adalah sebagai berikut:

$$
Y=a+b_{1} X_{1}+e
$$

Keterangan :

$\mathrm{Y}=$ manajemen laba

$\mathrm{a}=$ intersep (konstanta)

b1 $=$ koefisien regresi variabel independen 1

$\mathrm{X}_{1}=$ dicretionary accrual

$e=$ error term.

Tabel 4.5

Analisis linear regresi berganda

\begin{tabular}{|c|c|c|c|c|c|c|c|c|}
\hline \multicolumn{9}{|c|}{ Coefficients $^{\mathrm{a}}$} \\
\hline & & \multicolumn{2}{|c|}{$\begin{array}{c}\text { Unstandardized } \\
\text { Coefficients }\end{array}$} & \multirow{2}{*}{$\begin{array}{c}\begin{array}{c}\text { Standardized } \\
\text { Coefficients }\end{array} \\
\text { Beta }\end{array}$} & \multirow[t]{2}{*}{$\mathrm{T}$} & \multirow[t]{2}{*}{ Sig. } & \multicolumn{2}{|c|}{$\begin{array}{l}\text { Collinearity } \\
\text { Statistics }\end{array}$} \\
\hline \multicolumn{2}{|c|}{ Model } & B & $\begin{array}{l}\text { Std. } \\
\text { Error }\end{array}$ & & & & Tolerance & VIF \\
\hline \multirow[t]{2}{*}{1} & (Constant) & ,808 & ,074 & & 10,883 & ,000 & & \\
\hline & $\begin{array}{l}\text { Discretionary } \\
\text { Accrual (X1) }\end{array}$ &, 124 & , 049 & ,327 & 2,524 & ,014 & 895 & $\begin{array}{r}1,11 \\
7\end{array}$ \\
\hline \multicolumn{9}{|c|}{ a. Dependent Variable: Manajemen Laba (Y) } \\
\hline
\end{tabular}

Berdasarkan tabel di atas dapat diperoleh persamaan regresi linear berganda sebagai berikut:

Manajemen laba $(\mathrm{Y})=0.808+5.231 \mathrm{X}_{1}$

Dari persamaan regresi linear berganda di atas dapat diperoleh nilai konstantanya adalah sebesar 0.808. Artinya, jika variabel manajemen laba tidak dipengaruhi oleh discretionary accrual atau variabel bebasnya bernilai nol (0) maka besarnya rata-rata manajemen laba adalah 0.808 .

Nilai koefisien regresi pada variabel-variabel bebasnya menggambarkan jika variabel bebasnya dinaikan nilai sebesar satu unit dan variabel bebas lainnya konstan atau nilainya sama dengan nol, maka nilai variabel terikatnya akan naik sesuai dengan koefisien regresinya.

Koefisien regresi untuk variabel bebas $\mathrm{X}_{1}$ (discretionary accrual) bernilai positif, menunjukkan adanya hubungan yang searah antara discretionary accrual $\left(\mathrm{X}_{1}\right)$ dengan manajemen laba (Y). Koefisien regresi variabel $\mathrm{X}_{1}$ sebesar 0.124 mengandung arti untuk setiap pertambahan discretionary accrual $\left(\mathrm{X}_{1}\right)$ sebesar satu satuan akan menyebabkan kenaikan manajemen laba (Y) sebesar 0.124 .

Uji t digunakan untuk melihat signifikasi dari pengaruh independen secara individu terhadap variabel dependen dengan menganggap variabel lain bersifat konstan. Nilai t hitung digunakan untuk menguji apakah sebuah variabel bebas berpengaruh secara signifikan terhadap variabel tergantung atau tidak.

Uji t dapat dilakukan dengan cara memperbandingkan $t$ hitung dengan $t$ tabel. Adapun nilai $t$ tabel diperoleh dengan df: $\alpha,(\mathrm{n},-\mathrm{k})$ dimana $\alpha$ adalah tingkat signifikasi yang digunakan, $\mathrm{n}$ adalah jumlah pengamatan (ukuran sampel), dan k adalah jumlah variabel independen. Dasar pengambilan keputusannya adalah jika $\mathrm{t}$ hitung $>\mathrm{t}$ tabel, berarti $\mathrm{H}_{0}$ ditolak yang berarti bahwa variabel $X_{\mathrm{i}}$ 
berpengaruh signifikan terhadap variabel dependen, tetapi jika $\mathrm{t}$ hitung $\leq \mathrm{t}$ tabel, maka $\mathrm{H}_{0}$ diterima yang berarti bahwa variabel $X_{\mathrm{i}}$ tidak berpengaruh signifikan terhadap variabel dependen. Hasil selengkapnya dapat dilihat pada tabel 4.6 berikut.

Tabel 4.6

Tabel uji T

\begin{tabular}{|c|c|c|c|c|c|c|}
\hline \multicolumn{7}{|c|}{ Coefficients $^{\mathbf{a}}$} \\
\hline & & \multicolumn{2}{|c|}{$\begin{array}{c}\text { Unstandardized } \\
\text { Coefficients }\end{array}$} & $\begin{array}{l}\text { Standardized } \\
\text { Coefficients }\end{array}$ & $\mathrm{T}$ & Sig. \\
\hline \multicolumn{2}{|c|}{ Model } & B & Std. Error & Beta & & \\
\hline \multirow[t]{2}{*}{1} & (Constant) & 808 &, 074 & & 10,883 & 000 \\
\hline & Discretionary Accrual (X1) &, 124 & ,049 & ,327 & 2,524 & ,014 \\
\hline
\end{tabular}

Sumber: Output SPSS 24, 2017

Berdasarkan hasil perhitungan seperti dalam Tabel 4.6 dapat dijelaskan sebagai berikut: variabel discretionary accrual dengan nilai t hitung 2.524), t tabel 2.00247, (2.524 > 2.00247) dan signifikansi sebesar 0,014 ( $<0,05)$, artinya variabel discretionary accrual berpengaruh positif dan signifikan. Berdasarkan hasil uji statistik dan signifikansi bahwa variabel discretionary accrual berpengaruh positif dan signifikan terhadap manajemen laba. Hasil penelitian ini sejalan dengan penelitian Irreza dan Yulianti (2012) yang menyatakan bahwa discretionary accrual berpengaruh terhadap manajemen laba. Hasil yang sama didapatkan dari penelitian Taufik Budiman (2012) dan Sibarani \& Surtikanti (2015) menyatakan bahwa discretionary accrual berpengaruh signifikan terhadap manajemen laba. Hasil yang berbeda didapatkan dari penelitian Utari \& Widiastuti (2012) bahwa dewan discretionary accrual tidak berpengaruh terhadap manajemen laba.

\section{Kesimpulan}

Berdasarkan rumusan masalah, pengujian hipotesis dan pembahasan yang disampaikan pada bab-bab sebelumnya maka dapat disimpulkan bahwa: Discretionary accrual berpengaruh positif dan signifikan terhadap manajeman laba pada perusahaan manufaktur sektor otomotif dan komponen yang terdaftar di Bursa Efek Indonesia pada tahun 2012-2016. Penelitian ini diharapkan mempunyai dampak pada dua bagian, yaitu kontribusi teori, kontribusi praktik, dan kontribusi kebijakan. Penelitian ini diharapkan memberikan kontribusi secara ilimiah terhadap manajemen keuangan khususnya tentang manajeman laba yang dipengaruhi oleh discretionary accrual. Hasil penelitian ini diharapkan dapat menjadi acuan dalam pengembangan ilmu pengetahuan dan peneliti-peneliti lainnya. Hasil penelitian ini diharapkan dapat dijadikan acuan bagi pemilik perusahaan, investor dan pengambil kebijakan yang bisa dimanfaatkan dalam pengelolaan perusahaan. Dari hasil penelitian ini diketahui bahwa pengaruh discretionary accrual berpengaruh secara terhadap manajeman laba.

Penelitian ini telah dilakukan secara maksimal oleh peneliti namun peneliti menyadari bahwa masih banyak keterbatasan yaitu, antara lain Variabel yang mempengaruhi manajemen laba hanya terdiri dari variabel discretionary accrual. Sampel sasaran juga kurang dari 100 perusahaan dan jangka waktunya pengamatan juga hanya 5 tahun.

Untuk penelitian berikut diharapkan kepada peneliti untuk memasukkan variabel-variabel yang lebih banyak lagi dan jumlah sampel yang lebih besar lagi dan jangka waktu pengamatan yang lama. Adanya keterbatasan penelitian dengan menggunakan data sekunder yaitu terkadang laporan keuangan yang dipublish untuk umum tidak menunjukkan keadaan sesungguhnya Penelitian ini tidak dapat mewakili seluruh perusahaan yang terdaftar di Bursa Efek Indonesia Berdasarkan hasil pembahasan dan kesimpulan di atas maka peneliti dapat memberikan saran-saran sebagai berikut: Investor diharapkan dapat mengantisipasi manajemen laba yang dilakukan oleh pihak perusahaan dengan harapan investor mau menanamkan modalnya pada perusahaan tersebut. Manajemen harusnya jujur dan berhati-hati dalam mengelola perusahaan karena investor mengharapkan keuntungan dari investasi yang ditanamkan. 


\section{Referensi}

Arikunto, Suharsimi. (2006). Metodologi penelitian. Yogyakarta: Bina Aksara.

Bateman, Thomas S. dan Scott A. Snell. (2014). Manajemen kepemimpinan dan kerja sama dalam dunia yang kompetitif. Jakarta: Salemba Empat.

Dahlan, Muhammad. (2009). Analisis hubungan antara kualitas audit dengan diskretioneri akrual dan kebebasan auditor. Skripsi. Universitas Padjadjaran. Bandung.

De Angelo, L. E. (1986). Accounting number as valuation substitutes: a study of management buyouts of public stockholders. The Accounting Review, 59, 400- 420.

Dechow et al, (1995). Detecting earnings management. The Accounting Review, 70, 193-225.

Healy, P, dan Wahlen J. (1999). A review of the earnings manajement literature and its implications for standard setting. Accounting Horizon, 12(4).

Irreza dan Yulianti. (2010). Penggunaan komponen-komponen pembentuk pajak tangguhan dalam mendeteksi manajemen laba: Sebuah pendekatan baru di Indonesia. Universitas Indonesia. Simposium Nasional Akuntansi 13.

Kothari, S., Leone, A. J., dan Wasley, C. E. (2005). Performance matched discretionary accrual measures. Journal of Accounting and Economics, 39, 163-197.

Meutia, Intan. (2004). Pengaruh independensi auditor terhadap manajemen laba untuk kap big 5 dan non big 5. Jurnal Riset Akuntansi Indonesia, 7(3).

Moleong, L.J. (2011). Metodologi penelitian kualitatif edisi revisi. Bandung: PT Remaja Rosdakarya.

Muljono, Djoko. (2009). Pengantar PPh dan PPh 21 lengkap dengan undang- undang. Yogyakarta: Andi

Philips, J., M. Pincus, and S. Rego. (2003). Earnings management: New evidence based on deferred tax expenses. Working Paper SSRN, http://www.ssrn.com. Diakses tanggal 14 Oktober 2014.

Scott, W. R. (2012). Financial accounting theory 6th edition. Toronto: Pearson Education Canada

Scott, Wiliam R. (2015). Financial accounting theory seventh edition. United States : Canada Cataloguing

Sibarani, dan Surtikanti. (2015). Analisis pengaruh beban pajak tangguhan, discretioary accruals, dan arus kas operasi terhadap manajemen laba. Jurnal Riset Akuntansi dan Perpajakan, 2(1), 1931.

Sugiyono. (2013). Metode Penelitian Kuantitatif, Kualitatif dan R\&D. Bandung: Alfabeta.CV

Sugiyono. (2017). Metode Penelitian Kuantitatif, Kualitatif dan R\&D. Bandung : Alfabeta.CV

Sugiyono. (2016). Metode Penelitian Kuantitatif, Kualitatif dan R\&D. Bandung : Alfabet. CV

Sumomba, Christina Ranty dan Hutomo, YB. Sigit. (2012). Pengaruh beban pajak tangguhan dan perencanaan pajak terhadap manajemen laba. Yogyakarta: Jurnal Kinerja, 16(2), Hal 103-115.

Tomas J Sibarani et al. (2015). Analisis pengaruh beban pajak tangguhan, discretionary accruals, dan arus kas operasi terhadap manajemen laba. Jurnal Riset Akuntansi dan Perpajakan, 2(1):1931.

Taufik Budiman. (2012). Pengaruh beban pajak tangguhan dan akrual terhadap indikasi adanya praktik manajemen laba. Jurnal Ilmiah Mahasiswa.

Uma Sekaran, Bougie, Roger. (2010). Research methods for business: a skill building approach. 5th Edition. Wiley.

Utari Dewi, Eka Ni Putu Widiastuti. (2016). The usefulness of deffered tax expense in detecting earnings management. Journal of Business and Management, 18(2), 122- 129. 
Watts, Ross L. dan Jerold L. Zimmerman (1986). Positive Accounting Theory. USA: Prentice-Hall. Watts, R. L., and Zimmerman, J.L. (1990). Positive accounting theory: A ten year perspective.

American Accounting Association, 131-156.

yan. (2015). Terbukti palsukan laporan keuangan PT. Thosiba. money.cnn.com

Yin, and Cheng. (2004). Earning management of profit firms and loss firms in response to tax rate reduction. Review of Accounting and Finance, 3.

Yulianti. (2004). Kemampuan beban pajak tangguhan dalam mendeteksi manajemen laba.

Simposium Nasional Akuntansi VII Denpasar. 2-3 September 2004. 